\title{
ОСОБЕННОСТИ ОБУЧЕНИЯ ЛЕКСИЧЕСКРЙ СТОРОНЕ ПРИ ИЗУЧЕНИИ ФРАНЦУЗСКОГО ЯЗЫКА КАК ВТОРОГО ИНОСТРАННОГО НА БАЗЕ АНГЛИЙСКОГО
}

\author{
Париуткина Т.А. (научный руководитель)', \\ Факащук Н.Г. ${ }^{2}$, Лужных $A . A^{3}$
}

${ }^{1}$ Елецкий государственный университет им. И.А. Бунина, г. Елец, Российская Федерация

${ }^{2}$ Муниципальное Бюджетное Общеобразовательное Учреждение Средней Общеобразовательной Школы №1 с. Измалково, Липецкая область, Российская Федерация

${ }^{3}$ Муниципальное Бюджетное Общеобразовательное Учреждение Средней Общеобразовательной Школы с. Б. Боевка, Липецкая область, Российская Федерация

На сегодняшний день нет единой методики преподавания франиузского языка как второго иностранного. Каждый методист предлагает свою методику и приемы. В данной статье подробно было рассмотрено обучение лексическому аспекту (на базе английского языка), поскольку это неотъемлемая часть всех видов речевой деятельности. Кроме того, также были выделены методы обучения лексической стороне: метод сопоставления и метод языковой догадки.

Ключевые слова: лексическая сторона; метод обучения; франиузский как второй иностранный; виды речевой деятельности; словарный запас.

\section{THE FEATURES OF TEACHING THE LEXICAL SIDE WHEN LEARNING FRENCH AS A SECOND FOREING LANGUAGE BASED ON ENGLISH ONE}

\section{Parshutkina T.A. (advisor) ${ }^{1}$, Fakashchuk N.G. ${ }^{2}$, Luzhnykh A.A. ${ }^{3}$}

${ }^{1}$ Eletsk State University. I.A. Bunin, Yelets, Russian Federation ${ }^{2}$ Secondary School №1, Izmalkovo, Lipetsk region, Russian Federation

${ }^{3}$ Secondary School, Boevka, Lipetsk Region, Russian Federation

Today there is no unique teaching method of French as the second language. Each methodologist has his own Method and technic. This 
article is devoted to the teaching the lexical aspect (on the base of English language) because it is an essential part of all language activities. Furthermore some methods of teaching lexical aspect were found: comparison method and method of contextual guess.

Keywords: lexical aspect; teaching method; French as the second foreign language; language activities; vocabulary.

\section{Введение}

Идеального метода обучения французскому языку как второму иностранному, к сожалению, не существует. Каждый методист предлагает свою собственную методику и приемы. Можно назвать некоторые из них: интенсивный метод, активный метод, коммуникативный метод.

Главной задачей современной методики является разработка такого универсального метода, который собрал бы в себе все положительные стороны каждого из созданных методов [1].

Некоторые ученые используют методику обучения вторым иностранным языкам на базе уже изученного (родного или первого иностранного языка).

\section{Методы исследования}

В исследовании использовались методы анализа и синтеза литературы и словарей.

\section{Основная часть}

Лексическая сторона речи является неотъемлемой частью всех видов речевой деятельности (чтения, говорения, аудирования и письма) и может совпадать (не совпадать) на графическом уровне, а не на произносительном.

Несмотря на их принадлежность к разным языковым семьям (романской и германской), у рассматриваемых языков один предок латинский язык, что частично объясняет их совпадение.

Существуют следующие виды схожести/различия формы и значения: 
1. Полное совпадение формы и значения.

\begin{tabular}{|l|l|l|}
\hline \multicolumn{1}{|c|}{ Французского слова } & \multicolumn{1}{c|}{$\begin{array}{c}\text { Форма } \\
\text { английского слова }\end{array}$} & \multicolumn{1}{c|}{$\begin{array}{c}\text { Значение } \\
\text { слова }\end{array}$} \\
\hline Une question & A question & Вопрос \\
\hline Une table & A table & Стол \\
\hline Un village & A village & Село \\
\hline Une page & A page & Страница \\
\hline Un ballet & A ballet & Балет \\
\hline Une cuisine & A cuisine & Кухня \\
\hline Chic & Chic & Шикарный \\
\hline Une fiancé & A fiancé & Невеста \\
\hline
\end{tabular}

2. Частичное графическое несовпадение, но совпадение значений.

\begin{tabular}{|l|l|l|}
\hline \multicolumn{1}{|c|}{ Фронма } & \multicolumn{1}{c|}{$\begin{array}{c}\text { Форма } \\
\text { английского слова }\end{array}$} & \multicolumn{1}{c|}{$\begin{array}{c}\text { Значение } \\
\text { слова }\end{array}$} \\
\hline Une texte & A text & Текст \\
\hline Un verbe & A verb & Глагол \\
\hline Descendre & To descend & Спускаться \\
\hline Un exercice & An exercise & Упражнение \\
\hline Risquer & To risk & Рисковать \\
\hline Petit & Petite & Маленький, изящный \\
\hline Un exemple & An example & Пример \\
\hline Une addresse & An address & Адрес \\
\hline Une leçon & A lesson & Урок \\
\hline Intéressant & Interesting & Интересный \\
\hline Une mariage & A marriage & Свадьба \\
\hline Une famille & A family & Семья \\
\hline danser & To dance & Танцевать \\
\hline
\end{tabular}

3. Совпадение формы и полное несовпадение значения.

\begin{tabular}{|l|l|l|l|}
\hline $\begin{array}{c}\text { Форма } \\
\text { сранцузского } \\
\text { слова }\end{array}$ & \multicolumn{1}{|c|}{$\begin{array}{c}\text { Значение } \\
\text { французского } \\
\text { слова }\end{array}$} & \multicolumn{1}{c|}{$\begin{array}{c}\text { Форма } \\
\text { английского } \\
\text { слова }\end{array}$} & \multicolumn{1}{|}{$\begin{array}{c}\text { Значение } \\
\text { английского } \\
\text { слова }\end{array}$} \\
\hline Pain & Хлеб & Pain & Боль \\
\hline Coin & Угол & Coin & Монета \\
\hline Marcher & Ходить & To mash & Разминать \\
\hline Rester & Оставаться & To rest & Отдыхать \\
\hline Caractère & Характер & Character & Герой произведения \\
\hline Place & Площадь & Place & Место \\
\hline Large & Широкий & Large & Длинный \\
\hline
\end{tabular}


3.Р. Киреева и Х.Х. Гамилова рекомендуют начать обучение французскому языку с полных соответствий формы и значения, затем, перейти к работе с полными несоответствиями, используя проблемно-поисковую технологию концептуальных знаний [2].

Исходя из всего выше перечисленного, нами была выделена пара методов, характерная для изучения французского языка как второго иностранного на базе английского.

Одним из этих методов является метод сопоставления, который подразумевает не только изучение новой французской единицы, но и сравнение с той же единицей в английском языке.

Например, Un verbe - A verb - глагол

Данный метод ввода новой лексики больше характерен для начального этапа изучения второго иностранного языка. На последующих этапах мы рекомендуем использовать метод языковой догадки, суть которого заключается в переводе слов, словосочетаний и даже целых предложений основываясь на знания первого иностранного языка.

Ниже приведено несколько предложений в качестве примера.

Elle m'a posé une question intéressante. - Она задала мне интересный вопрос.

La cuisine de ce pays est très inhabituelle. - Кухня этой страны очень необычная.

Regardez à la page 10. - Посмотрите на страницу 10.

\section{Заключение}

Рассмотрев особенности обучения французскому языку как второму иностранному на базе английского, мы приходим к выводу, что данное предложение имеет огромный потенциал и может быть успешно использован учителями и преподавателями французского языка.

\section{Список литературы}

1. Барышников Н.В. Обучение французскому языку в средней школе: вопросы и ответы: Кн. Для учителя. М.: Просвещение. 1992. 128 с. 
2. Киреева 3.Р., Особенности обучения французскому языку как второму иностранному на языковом факультете / 3.Р. Киреева, Х.Х. Галимова // Филологические науки. Вопросы теории и практики. 2015. № 5 (47). С. 103-106.

\section{References}

1. Baryshnikov N.V. Obuchenie francuzskomu yazyku v srednej shkole: voprosy i otvety [Teaching the French language in middle school: questions and answers]: Kn. Dlya uchitelya. M.: Prosveshchenie. 1992. $128 \mathrm{~s}$.

2. Kireeva Z.R., Osobennosti obucheniya francuzskomu yazyku kak vtoromu inostrannomu na yazykovom fakul'tete [The peculiarities of teaching the French language as the second one on the language faculty] / Z.R. Kireeva, H.H. Galimova // Filologicheskie nauki. Voprosy teorii i praktiki. 2015. № 5 (47). S. 103-106. 